\title{
Vici syndrome
}

INSERM

\section{Source}

INSERM. (1999). Orphanet: an online rare disease and orphan drug data base. Vici syndrome. ORPHA:1493

Vici syndrome is a very rare and severe congenital multisystem disorder characterized by the principal features of agenesis of the corpus callosum, cataracts, oculocutaneous hypopigmentation, cardiomyopathy and combined immunodeficiency. 